\title{
Insights into wolf presence in human- dominated landscapes: the relative role of food availability, humans and landscape attributes
}

Luis Llaneza $^{1,2 \star}$, José V. López-Bao ${ }^{3,1 \star}$ and Víctor Sazatornil ${ }^{1}$

${ }^{1}$ A.RE.NA. Asesores en Recursos Naturales, S.L. Perpetuo Socorro $n^{\circ} 12$-Entresuelo, 2B, 27003, Lugo, Spain, ${ }^{2}$ Departamento de Bioloxía Celular e Ecoloxía, Faculta de Bioloxía. Universidad de Santiago de Compostela. Campus Sur, 15782, Santiago de Compostela, Spain, ${ }^{3}$ Department of Conservation Biology. Estación Biológica de Doñana (EBD-CSIC), c/ Américo Vespucio s/n, Isla de la Cartuja. 41092 Sevilla, Spain

${ }^{*}$ Correspondence: Luis Llaneza, A.RE.NA. Asesores en Recursos Naturales, S.L. Perpetuo Socorro no12-Entresuelo, 2B, 27003, Lugo, Spain.

E-mail: llaneza@arenatural.com

José V. López-Bao, A.RE.NA. Asesores en Recursos Naturales, S.L. Perpetuo Socorro $\mathrm{n}^{\circ}$ 12-Entresuelo, 2B, 27003, Lugo, Spain.

E-mail: jv.lopezbao@gmail.com

\begin{abstract}
Aim Understanding which human or environmental factors interact to enable or to limit the occurrence and persistence of large carnivores in human-dominated landscapes is an important issue for their effective conservation, especially under the current scenario of global change where most of their former habitat is being transformed by humans.
\end{abstract}

Location NW Iberian Peninsula.

Methods We combine data on the distribution of Iberian wolves (Canis lupus signatus) living in a human-dominated landscape in NW Spain and variation and partitioning methods to investigate the relative importance of three groups of predictors: food availability, humans and landscape attributes - each group expected to have unequal effects on wolf reproduction and survival - and their interactions on the occurrence of this species.

Results We found that the group of predictors related with landscape attributes (altitude, roughness and refuge) strongly determined wolf occurrence, followed by humans and food availability. Variance partitioning analysis revealed that the three most important components determining wolf occurrence were related with landscape attributes: (1) the joint effects of the three predictor groups, (2) the joint effect of humans and landscape attributes and (3) the pure effect of landscape attributes. Altitude had the main independent contribution to explain the probability of wolf occurrence.

Main conclusions In human-dominated landscapes, the occurrence of wolves is the result of a complex interaction among several environmental and human factors. Our results suggest that the characteristics of the landscape (spatial context) - factors associated with the security of wolves facilitating that animals go unnoticed by humans, wolf movements, dispersal events and short-time colonization - become more important in human-dominated landscapes and may have played a key role in the occurrence and persistence of this species throughout decades modulating the relationship between humans and wolf distribution.

\section{Keywords}

Canis lupus signatus, carnivore conservation, carnivore persistence, humandominated landscapes, landscape context, refuge, wolf presence.

\section{INTRODUCTION}

The ability of large carnivores to persist in human-dominated landscapes has aroused debate in recent years (Woodroffe, 2000; Linnell et al., 2001; Basille et al., 2009). Large carni- vores are particularly sensitive to human development, with human density, human activities and associated humancarnivore conflict being key factors determining their occurrence and persistence (Woodroffe, 2000; Woodroffe et al., 2005). However, in some areas, these species are able to 
persist at high human densities and at high levels of landscape transformation, suggesting a regional variation in the species' sensitivity to humans and their activities, driven by other human, biological or environmental factors (Woodroffe, 2000; Linnell et al., 2001; Cardillo et al., 2004; Blanco \& Cortés, 2007; Basille et al., 2009; Agarwala et al., 2010). In anthropogenic landscapes, the occurrence and persistence of large carnivores seem to be modulated by strong interactions among factors that affect reproductive rates, such as food availability (Fuller \& Sievert, 2001; Basille et al., 2009), and factors that affect survival such as human activity or landscape context, which can reduce human pressure (Woodroffe \& Ginsberg, 1998). However, the relative importance of these blocks (sometimes composed by several factors) and their interactions in determining the occurrence of these predators in human-dominated landscapes remains poorly understood (e.g. Boitani, 2000).

Along these lines, wolves (Canis lupus) living in humandominated landscapes are a good model species to tackle this question. Broadly, wolf habitat tolerance is shaped by food availability and mortality risk (Fuller, 1989; Mech, 1995; Mladenoff et al., 1995; Massolo \& Meriggi, 1998; Fritts et al., 2003; Jedrzejewski et al., 2008; Musiani et al., 2010). However, a lack of knowledge remains about how these factors interact to enable or to limit wolf presence in human-dominated landscapes (Boitani, 2000). In Eurasia, wolves persist in some areas where human densities are remarkably higher ( $>30$ inhabitants $\mathrm{km}^{-2}$ and $>1 \mathrm{~km}$ of roads $\mathrm{km}^{-2}$; Massolo \& Meriggi, 1998; Blanco \& Cortés, 2007; Theuerkauf et al., 2007; Agarwala et al., 2010) than the upper threshold value reported in North America $\left(<13\right.$ inhabitants $\mathrm{km}^{-2}$ and $<0.7 \mathrm{~km}$ of roads $\mathrm{km}^{-2}$; Thiel, 1985; Mech, 1989; Mladenoff et al., 1995, 2009; but see Merrill, 2000). Moreover, these high human and road densities are accompanied by high levels of human activity and settlements (Massolo \& Meriggi, 1998; Ciucci et al., 2003; Blanco \& Cortés, 2007; see below).

In Europe, as consequence of severe persecution during the last two centuries, wolves were reduced to few small isolated populations (Promberger \& Schroder, 1993). In the Iberian Peninsula, a remnant wolf population (Canis lupus signatus) reached its lowest point in the 1970s, with wolves surviving mainly in the north-west (Blanco \& Cortés, 2002; Fig. 1a). Subsequently, this population started to increase and expanded southwards and eastwards (Blanco \& Cortés, 2002). Interestingly, wolves persisted in an area - Galicia, NW Spain (Fig. 1a,b) - with high levels of human density and activity (around 80-90 inhabitants $\mathrm{km}^{-2}$ during the last five decades; 93 inhabitants $\mathrm{km}^{-2}$ and 1 settlement $\mathrm{km}^{-2}$ in the last decade; INE, 2009; see Agarwala et al., 2010 for a similar scenario), and where the human-wolf conflict has been evident for a long time (Blanco \& Cortés, 2002). In fact, recent studies suggest that wolf range in Galicia did not vary remarkably in the last 1.5 centuries (Nunez-Quirós et al., 2007). For example, at the beginning of the 2000s wolf presence and abundance in Galicia were remarkable with at least 68 different wolf packs identified (c. 2.25 wolf packs per $1000 \mathrm{~km}^{2}$; Llaneza \& Ordiz, 2003; Llaneza et al., 2004, 2005a).

Thus, wolves living in Galicia provide a good opportunity to investigate how a group of predictors representing food availability, humans and landscape attributes, along with their interactions, determine the occurrence of a large predator in a human-dominated landscape. We expected that (1) wolves should select areas with high prey abundance, (2) taking into account previous wolf habitat models, wolves should avoid the areas of highest human densities and activity levels (in most known cases, during the study period wolf mortality (a)

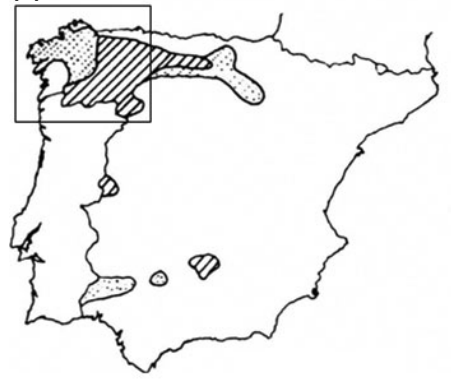

(c)

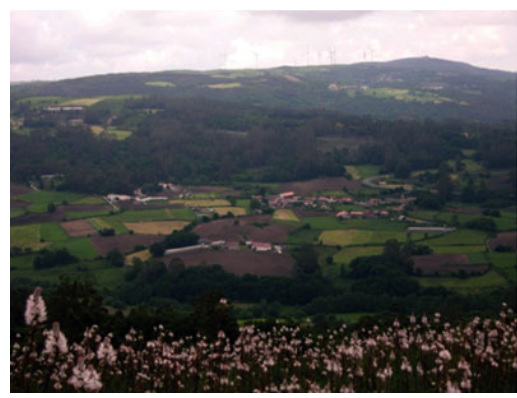

(b)
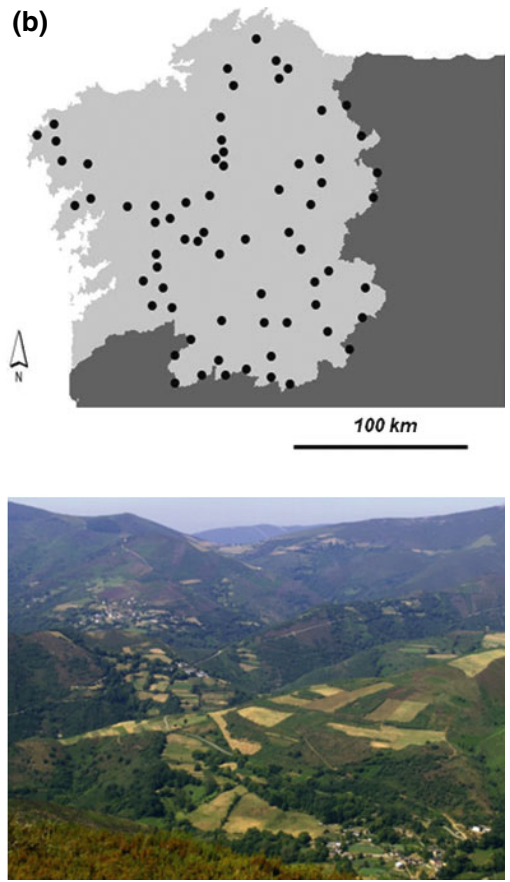

Figure1 (a) Approximate distribution of wolves in Spain around 1970s extracted from Valverde (1971). Dotted area: uncommon; striped area: common. (b) Highlighted area denote the geographical location of Galicia (NW Spain). Approximate location of known wolf packs in Galicia in the period 1999-2003 (see text for details). (c) Pictures showing typical human-dominated landscapes where wolves commonly occur in Galicia. 
was caused by humans in $91 \%$ of cases: $65 \%$ were road killed, $20 \%$ died by poaching or illegal hunting, and $6 \%$ were legally hunted; Llaneza \& Ordiz, 2003; Llaneza et al., 2004, 2005a), but showing higher tolerance levels for these factors than previously reported in non-human-dominated landscapes, and (3) wolves should strongly select inaccessible and safe places (i.e. refuge) to decrease human-mediated mortality risks. Human density and the type of human activities carried out in a given area may be important factors determining the level and the type of human pressure on a wolf population (Fuller, 1989; Mech, 1995), but landscape attributes may drive this human-wolf interaction by providing protection from humans. The availability of areas that are hardly accessible to humans may ensure the occurrence of large predators such as wolves by decreasing human pressure (Corsi et al., 1999; Glenz et al., 2001). In this regard, we predicted that landscape attributes should be a key group of predictors enabling the occurrence of this species in humandominated landscapes.

\section{METHODS}

\section{Study site}

Fieldwork was carried out in Galicia (NW Spain; Fig. 1a,b), covering $c .30,000 \mathrm{~km}^{2}$. The study area is characterized by a human-dominated landscape with human settlements $(\geq 10$ buildings) widely scattered ( 1 human settlement $\mathrm{km}^{-2}$; c. $50 \%$ of human settlements of Spain are located in Galicia) and a mean human population density around 93 inhabitants $\mathrm{km}^{-2}$ (INE, 2009). The percentage of people living in small villages in Galicia ( $<10$ buildings) is $16.5 \%$, whereas this percentage for the overall country is four times lower. Consequently, the high geographical dispersion of human settlements implicitly requires a well-developed paved road network (mean paved road density $2.7 \mathrm{~km} \mathrm{~km}^{-2}$ ). Most human settlements in the area are placed at medium-low altitudes in the valleys and/or in flat areas. As a result, human activities decrease with increasing altitude and topographic roughness (see also Glenz et al., 2001 for a similar scenario; Fig. 1c).

As a result of long-standing traditional human management for agriculture and livestock in Galicia, most of the territory is comprised of a patchy and heterogeneous landscape (Fig. 1c) made up of cropland, pasture, scrub, semi-natural deciduous forest (Quercus robur, Quercus pyrenaica and Betula alba) and forest plantations (Eucalyptus spp. and Pinus spp.). It is worth mentioning that the cover percentage of pastures and crops in Galicia is $39 \%, 23 \%$ for forest plantations and $26.6 \%$ for scrublands, which have been transformed by human activities. Less than $10 \%$ of this area is occupied by woodland deciduous forest and most of them have been managed for long time (i.e. timber harvest). As in many rural areas of Europe, dramatic declines in livestock and the swift process of depopulation and land abandonment during the last third of the 20th century (Gómez-Sal et al., 1993; Roura-Pascual et al., 2005; Munilla-Rumbao et al., 2008) led to an increase in the cover of scrubland and forest plantations and a decrease in agricultural fields (see Munilla-Rumbao et al., 2008 for an example in the East part of Galicia).

\section{Wolf survey}

Data on the distribution of wolves come from regional wolf surveys carried out in the summer-autumn periods (breeding and pre-dispersal periods) between 1999 and 2003 (Llaneza \& Ordiz, 2003; Llaneza et al., 2004, 2005a). Wolf presence was determined by means of indirect signs such as faeces and ground scratch marks, excluding tracks owing to the difficulty of differentiating dog tracks from wolf tracks (Harris \& Ream, 1983). Shape, size, contents, smell and spatial position were, in combination, diagnostic attributes of wolf faeces. The criteria used were considered reliable since a trial using these criteria to assign wolf faeces and a parallel DNA analyses confirmed that $90 \%$ of faeces $(n=108)$ were correctly assigned to wolves (R. Godinho et al., unpublished data). Ground scratching is a form of territorial marking, which in addition to olfactory information involves a visible sign and it is commonly placed on paths (Zub et al., 2003). Size, length, intensity and the presence of other wolf signs such as faeces are commonly used to determine the identity of these marks. Overall, 1689 wolf signs (1594 faeces and 95 scratch marks; $100 \%$ of positive gridcells by scratch marks were also confirmed by faeces) were located and used to determine wolf presence.

As random sampling is not effective to locate wolf signs (e.g. Llaneza et al., 2005b), surveys were focused on landscape features often used by wolves as marking places. We therefore searched for wolf signs along transects, on foot or using a vehicle $\left(<10 \mathrm{~km} \mathrm{~h}^{-1}\right)$ following paths, dirt roads, forest trails, firebreaks and crossroads, because wolves locate most of their faecal marking sites (territorial marking sites) in these places (Mech \& Boitani, 2003; Barja et al., 2004; Llaneza et al., 2005b). Further details about the monitoring procedure are given in Llaneza et al. (2005b). The total number of transects used was 1204 with a total of $5631.4 \mathrm{~km}$ surveyed (a mean $\pm \mathrm{SD}$ of $4.7 \pm 3 \mathrm{~km}$ per transect).

We took the Universal Transverse Mercator (UTM) coordinates of all wolf signs to determine the presence of this species on a $5 \times 5 \mathrm{~km}$ grid-cell basis. Out of the 1323 grid-cells that make up the study area, $862\left(65 \% ; 21,550 \mathrm{~km}^{2}\right)$ were searched and wolf signs were located in $31 \%$ of them $(47 \%$ of the total grid-cells sampled). Transect length in all grid-cells was $>1 \mathrm{~km}$ with a mean of $6.5 \mathrm{~km}$ (range $1-8 \mathrm{~km}$ ) and a mean of 4.2 wolf signs were found by positive cell $(\mathrm{SD}= \pm 3.5$; range $1-34)$. Because of the extensive movements of wolves, often occupying territories several times larger than our survey grid-cells (> $100 \mathrm{~km}^{2}$; Blanco \& Cortés, 2007; Jędrzejewski et al., 2007) and the constraints associated with our sampling protocol (focused on territorial marks), we excluded from analyses all grid-cells where wolf presence was not detected but which adjoined grid-cells with wolf presence, with the aim of reducing misidentification of wolf absence grid-cells. 


\section{Human and environmental variables}

We used twelve predictors grouped into three blocks: food availability, humans and landscape attributes, each expected to have unequal effects on wolf reproduction and survival.

\section{Food availability}

Dietary studies carried out in Galicia have shown that the most important food resources for wolves in this area were livestock, mainly horses (Equus caballus), cattle (Bos taurus), sheep (Ovis aries), pigs (Sus scrofa domesticus), goats (Capra hircus) and carrion (Guitián et al., 1979; Cuesta et al., 1991; Sazatornil, 2008). Locally, wild ungulates (i.e. game species), particularly wild boar (Sus scrofa) and roe deer (Capreolus capreolus) can be also important (Guitián et al., 1979; Cuesta et al., 1991; Barja, 2009). Generally, anthropogenic food resources are more important than wild prey (Guitián et al., 1979; Cuesta et al., 1991; Sazatornil, 2008). In fact, excluding some local context (Guitián et al., 1979; Barja, 2009), several studies showed that wild prey composed $<15 \%$ of the diet of wolves (Cuesta et al., 1991; Sazatornil, 2008; Palacios et al., 2009).

We estimated food availability as the densities of wild and domestic ungulates within each sampled grid-cell (i.e. an estimate of the biomass available of each food type). Data on approximate numbers of wild ungulates come from the official game statistics held by the Environmental Council of Galicia between 1999 and 2004 at the level of game preserve (mean area $=59 \mathrm{~km}^{2}$; range $1-459 \mathrm{~km}^{2} ; n=501 ; 50 \%$ of game preserves have an area $<50 \mathrm{~km}^{2}$; Xunta de Galicia, 2005) and were corrected by hunting effort (number of beats). In the case of Galicia, official game statistics are reliable as regards the differences in wild ungulate abundance among different zones. Since wolves mainly fed on humanorigin food sources, we pooled together wild boar and roe deer in a variable representing the density of game species (i.e. wild prey). Data on livestock were taken from the Rural Council of Galicia at the level of council (mean area $=90 \mathrm{~km}^{2}$; range $1-430 \mathrm{~km}^{2} ; n=323 ; 31 \%$ of councils have an area $<50 \mathrm{~km}^{2}$; Xunta de Galicia, 2003). We used five variables representing those most important domestic species in the diet of wolves either in number of prey items or in biomass: horse, cattle, sheep, goat and pig (e.g. Sazatornil, 2008). All variables were transformed to number of heads of animals per square kilometre. As a grid-cell often overlap more than one game preserve or council, data on wild prey or livestock from each overlapping administrative figure were weighted for each grid-cell in relation to their proportion of the total cell area.

\section{Humans}

We used density of human population, density of buildings and density of roads as measures of human presence and activity within each sampled grid-cell. Data on density of population and density of buildings were taken from the
National Institute of Statistics (INE, 2009) at the level of parish (mean area $=7.8 \mathrm{~km}^{2}$; range $0.08-75 \mathrm{~km}^{2} ; n=3797 ; 76 \%$ of parish have an area $<10 \mathrm{~km}^{2}$ whereas $97 \%$ have an area $<25 \mathrm{~km}^{2}$ ) and were measured as number of inhabitants per square kilometre and number of buildings per square kilometre, respectively. Again, for each grid-cell, we weighted data on human and settlement densities from each overlapping parish in relation to their proportion of the total cell area. Data on road density were taken from Environmental Council of Galicia (Xunta de Galicia, 2003). We grouped all types of paved roads in a single predictor representing accessibility of humans and risk of road mortality. We did not consider unpaved roads. We generated this variable as the ratio between the sum of the total lengths of all roads and the surface area of each grid-cell $\left(\mathrm{km} \mathrm{km}^{-2}\right)$.

\section{Landscape attributes}

We compiled three variables associated with low human densities and activities, and safe places for wolves: mean altitude, roughness and refuge. We calculated the mean altitude (metres) by averaging altitudes of all $100 \times 100 \mathrm{~m}$ raster cells included in each sampled grid-cell. We calculated roughness (metres) as the standard deviation of the altitudes of all $100 \times 100 \mathrm{~m}$ raster cells included in each sampled grid-cell. Finally, in spite of the fact that wolves are highly adaptable to a wide range of vegetation types (even areas without plant cover; Boitani, 1982; Mech \& Boitani, 2003; Jedrzejewski et al., 2008), we counted as refuge sites only those vegetation types that could effectively conceal wolves (vegetation $>50 \mathrm{~cm}$ high): scrublands, woodlands and forest plantations. Functionally, these vegetation types provide similar conditions of refuge and resting site for wolves (L. Llaneza, J.V. López-Bao \& V. Sazatornil, unpublished data), and therefore were pooled together in a single variable denominated 'refuge'. This variable was the sum of the surface occupied by scrublands, woodlands and forest plantations within each sampled grid-cell. Data on vegetation types and the proportions of the different plant covers were obtained from the Spanish Forest Map (scale 1:200,000; Ruíz de la Torre, 2001).

\section{Statistical analyses}

We used variation and hierarchical partitioning methods that allow the addressing of collinearity problems which sometimes can hinder the detection of key factors underlying studied processes (Mac Nally, 2000; Mac Nally \& Horrocks, 2002). These statistical methods decompose the variation in response variables into independent components, which reflect the relative importance of individual predictors or groups of predictors and their joint effects (Anderson \& Gribble, 1998; Heikkinen et al., 2005).

Before carrying out analyses, we built matrices of Spearman correlation coefficients to explore collinearity between predictors. Only the pair of variables density of buildings and density of population showed high correlation $\left(r_{\mathrm{s}}=0.8\right)$, but we 
retained both predictors because of their different biological meanings (Green, 1979).

We used a variance partitioning approach to decompose the variation in the occurrence of wolves among the three groups of predictors: food availability, humans and landscape attributes. We used a series of generalized linear models (GLM) with binomial errors and logit link to decompose the deviance among these three groups of predictors (i.e. partial models; Borcard et al., 1992; Heikkinen et al., 2005). Within each block, forward stepwise procedures, starting from a full model including all predictors, were performed to exclude within each group variables that did not contribute significantly $(P>0.05)$ to the explained deviance. Thus, final candidate models included only significant variables. In addition, we checked for Akaike's information criterion (AIC) differences in all steps of the models (Burnham \& Anderson, 2002). We obtained the total explained variation in the occurrence of wolf in our data set by carrying out a GLM with all the selected statistically significant variables of the three groups of predictors (i.e. the general model). The deviance explained by each of the previous models was calculated as the percentage of the total deviance explained by the respective general model. Variation partitioning led to eight fractions (Anderson \& Gribble, 1998; Heikkinen et al., 2005): (1) pure effect of food availability alone; (2) pure effect of humans alone; (3) pure effect of landscape attributes alone, and combined variance attributable to the joint effects of (4) food availability and humans; (5) food availability and landscape attributes; (6) humans and landscape attributes; (7) the three groups of predictor variables and finally (8) unexplained variance (see Fig. 2).

Values of human and environmental variables for neighbouring grid-cells may be more similar than they would be for random. Therefore, to separate the independent effects of explanatory variables from those accounting for spatial autocorrelation, we corrected for spatial autocorrelation in all models by including a spatial term of the form ' $x+y+x^{2}+$ $x y+y^{2}+x^{3}+x^{2} y+x y^{2}+y^{3}$ ' (Legendre \& Legendre, 1998). The spatial coordinates of the sampled grid-cells (lower-right ' $x$ ' and ' $y$ ' UTM coordinates) were centred on their respective means to reduce collinearity with higher order terms (Legendre \& Legendre, 1998) and standardized to unit variance.

Then, we performed a hierarchical partitioning including only those predictors retained as significant in previous models to identify their independent and conjoint contributions with all other significant variables (Chevan \& Sutherland, 1991; Mac Nally, 2000). Hierarchical partitioning was conducted using logistic regression and log-likelihood as the goodness-of-fit measure. This statistical procedure allowed us to identify those predictors with an important independent - not partial correlation with the probability of wolf occurrence (Mac Nally \& Horrocks, 2002). Statistical significances of the independent contributions of selected predictors were tested by a randomization procedure (100 randomizations), which yielded $Z$-scores for the generated distribution of randomized independent contributions and an indication of statistical

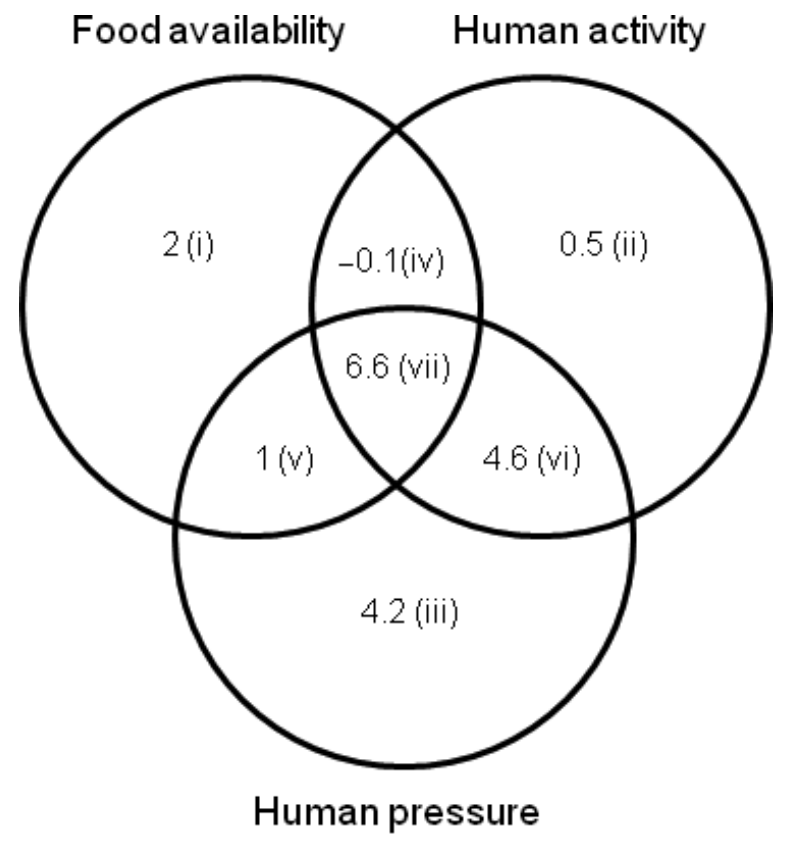

(viii) Un explained variance: $81.2 \%$

Figure2 Results of variance partitioning for the occurrence of wolves in Galicia (NW Spain) in terms of the fractions of variance explained. Variance is explained by three groups of predictors: food availability, humans and landscape attributes; (i), (ii), and (iii) are unique effects of food availability, humans and landscape attributes, respectively; while (iv), (v), (vi) and (vii) are fractions indicating their joint effects. (viii) refer to undetermined variance.

significance $(P<0.05)$ based on an upper 0.95 confidence limit $(Z \geq 1.65$; Mac Nally \& Horrocks, 2002). We used the $\mathrm{R}$ 2.8.1 statistical software (R Development Core Team, 2008) and the hier.part package (Walsh \& Mac Nally, 2008) for all the regression and partitioning analyses.

\section{RESULTS}

The group of predictors that accounted the highest proportion of the variation in the wolf distribution data was landscape attributes $(16.4 \%)$, followed by humans $(11.7 \%)$ and food availability (9.6\%; Fig. 2). Final models for the occurrence of wolves from the three predictor groups are shown on Table 1. For food availability, the model predicted a significant increase in the probability of wolf occurrence only with increased densities of horses and wild ungulates (Table 1; Fig. 3). For humans, the model predicted an increasing probability of wolf occurrence with lower densities of buildings and roads (Table 1; Fig. 3). Interestingly, human density was not selected in the final model of humans. In fact, mean human population density in grid-cells with wolf presence was highly variable (mean $\pm \mathrm{SD}$ of $28 \pm 32$ inhabitants $\mathrm{km}^{-2}$, range 0.6-247.6). Wolves occurred in Galicia in areas with remarkably high densities of paved roads (mean $\pm \mathrm{SD}$ of $1.2 \pm 0.7 \mathrm{~km} \mathrm{~km}^{-2}$, range $0-3.7$ ) and settlements (mean \pm SD of $14.3 \pm 12.1$ buildings $\mathrm{km}^{-2}$, range $0-131.7$ ). Finally, we detected a positive 
Table1 Generalized linear models obtained for the probability of wolf occurrence in Galicia (NW Spain). Models were built separately for each of the predictor groups before applying the variance partitioning approach. The spatial correction term was included in all the models but is not shown in the table for simplicity. Degrees of freedom: 64. Final candidate models were always those with the best Akaike's information criterion (AIC) or with a difference $<1$ with regard to the best model (models with a difference $<2$ units are commonly considered as alternatives; Burnham \& Anderson, 2002).

\begin{tabular}{llcllc}
\hline $\begin{array}{l}\text { Predictor } \\
\text { group }\end{array}$ & Variable & Estimate & SE & $Z$ & $P$ \\
\hline $\begin{array}{l}\text { Food } \\
\text { availability }\end{array}$ & $\begin{array}{l}\text { Density of horses } \\
\text { Density of } \\
\text { game species }\end{array}$ & 0.02 & 0.01 & 5.33 & $<0.0001$ \\
Humans & Density of roads & -0.14 & 0.29 & 2.42 & 0.015 \\
& Density of buildings & -0.03 & 0.01 & -4.96 & $<0.0001$ \\
Landscape & Mean altitude & 0.01 & 0.01 & 7.94 & $<0.0001$ \\
attributes & Refuge & 0.15 & 0.05 & 2.72 & 0.006 \\
& Roughness & 0.01 & 0.01 & 2.05 & 0.040 \\
\hline
\end{tabular}

effect for all predictors tested within the landscape attributes group (mean altitude, roughness and refuge) on the probability of wolf occurrence (Table 1; Fig. 3).
Together, food availability, humans and landscape attributes models explained $18.8 \%$ of the deviance in the data set (Fig. 2). Of the total deviance explained (Fig. 2), the most important components were the joint effect of the three predictor groups (vii $=35 \%$ ), followed by the joint effect of humans and landscape attributes $(\mathrm{vi}=24 \%)$ and the pure effect of landscape attributes $(\mathrm{iii}=22 \%)$. The spatial term accounted for a high proportion of variability in the data set (Fig. 4), being more important for food availability (79\%) than for humans and landscape attributes (43\% and 47\% respectively; Fig. 4).

Results of hierarchical partitioning were in accordance with those of variation partitioning. Hierarchical partitioning analysis revealed that mean altitude had the highest proportion of independent contribution to explaining the probability of wolf occurrence $(35.6 \%)$, followed by density of buildings $(23.8 \%)$, density of horses (13.4\%) and density of roads (11.2\%; Fig. 5). The remaining predictors showed independent contributions $<10 \%$ (Fig. 5). All predictors showed remarkable proportions of joint contributions ( $>48 \%$ of explained variance excluding density of horses; Fig. 5). The independent effects of all included variables were statistically significant (Table 2). Overall, landscape attributes was the group of predictors most important in explaining wolf occurrence (48\%), followed by humans (35\%) and food availability (17\%).
FOOD AVAILABILITY

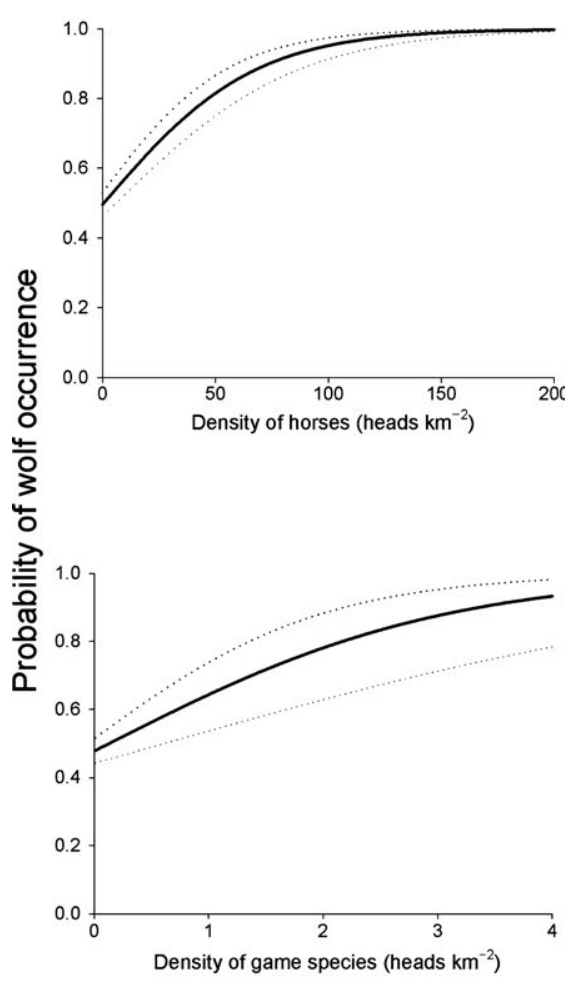

HUMANS
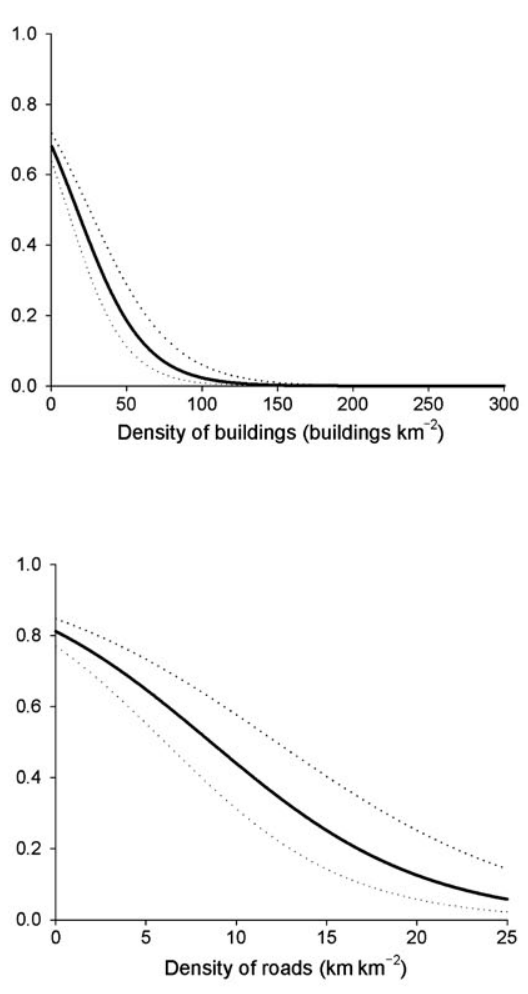

LANDSCAPE ATTRIBUTES

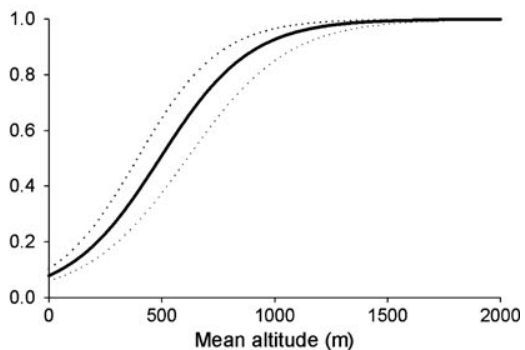

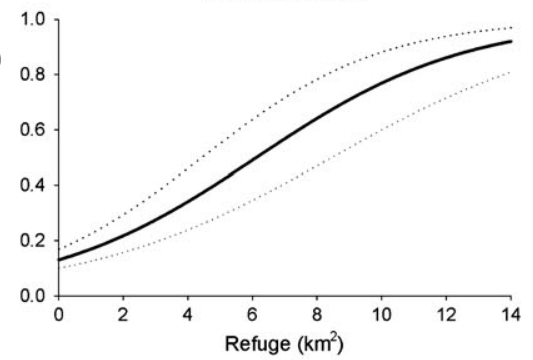

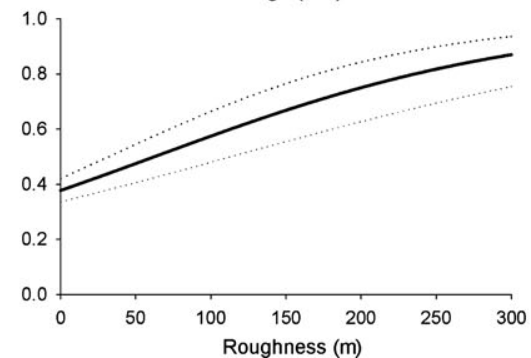

Figure3 Predicted probability of wolf occurrence in Galicia (NW Spain) against the selected statistically significant variables of the three groups of predictors (food availability, humans and landscape attributes). 


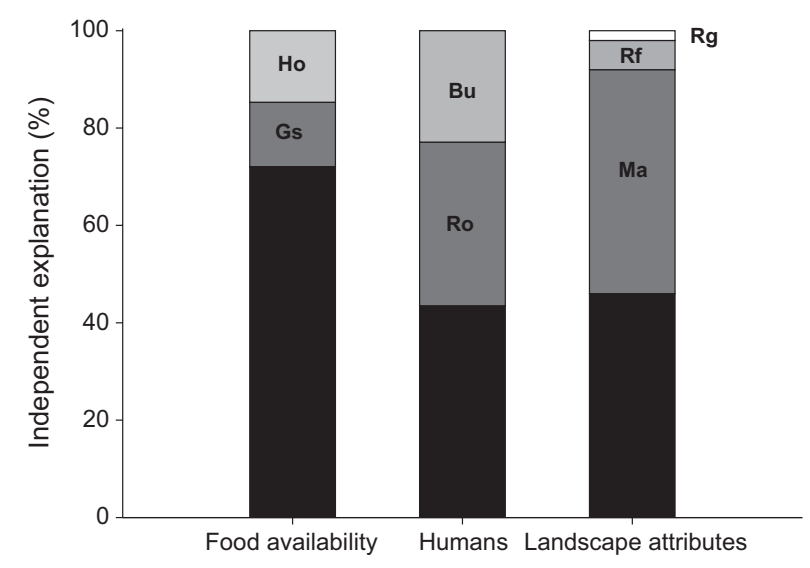

Figure4 Results of the deviance partitioning analysis performed to assess the independent contribution of the explanatory variables included in the final models. Black: deviance explained by the spatial pattern of the sampled grid-cells. Ho: density of horses; Gs: density of game species; Bu: density of buildings; Ro: density of roads; Rg: roughness; Rf: refuge and Ma: Mean altitude.

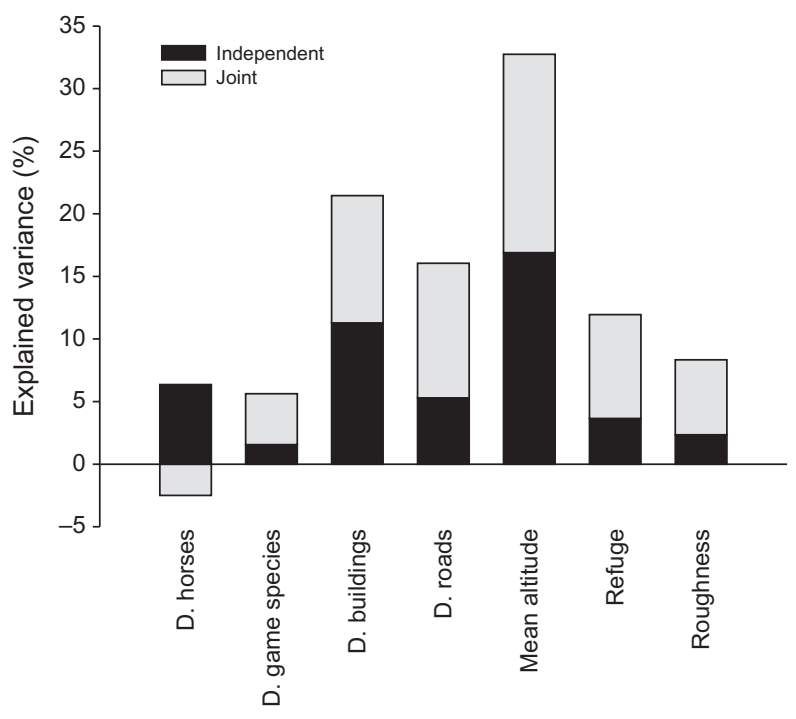

Figure 5 The independent and joint contributions (percentage of the total explained variance) of the variables selected for the probability of wolf occurrence in Galicia (NW Spain), as estimated from hierarchical partitioning.

\section{DISCUSSION}

Studies on the factors that enable or limit the occurrence of wolves have yielded similar results throughout its range (e.g. Fuller, 1989; Mladenoff et al., 1995, 2009; Massolo \& Meriggi, 1998; Corsi et al., 1999; Jedrzejewski et al., 2008). Generally, the importance of human-related factors (human density, settlements or road density) has been emphasized along with the abundance of prey and the presence of refuge areas. Accordingly, despite the observational character of this study, we found that wolves selected areas with abundant prey
Table2 Results of the randomization tests for the independent contributions of separate predictor variables in hierarchical partitioning to explaining variation in the occupancy of wolves in Galicia (NW Spain).

\begin{tabular}{lrl}
\hline Variable & $Z$-score & $P$ \\
\hline Density of horses & 8.94 & $<0.05$ \\
Density of game species & 2.33 & $<0.05$ \\
Density of buildings & 35.94 & $<0.05$ \\
Density of roads & 7.72 & $<0.05$ \\
Mean altitude & 37.69 & $<0.05$ \\
Refuge & 4.44 & $<0.05$ \\
Roughness & 4.55 & $<0.05$ \\
\hline
\end{tabular}

(prediction 1), low human presence (prediction 2) and less access for humans (prediction 3 ).

The complexity of the behaviour of wolves and the fact that this species can adapt to a wide range of environments provided that food and refuge are available (Mech \& Boitani, 2003) may explain the relatively low percentage of deviance explained together by food availability, humans and landscape attributes models (see also Mech, 2006). Our results suggest that food availability did not seem to be a limiting factor for wolves in our study area, and we point out that this fact may be linked to the low percentage of deviance explained. Alternatively, we cannot exclude the possibility that important determinants of wolf presence not considered in this study caused the large amount of unexplained variance. We suggest that in human-dominated landscapes just above the minimal requirements of food availability and refuge, which make the presence of this species possible, the level of tolerance towards wolves within each local context will play an important role driving the occurrence and persistence of wolves (NaughtonTreves et al., 2003; Karlsson \& Sjöström, 2011). In this regard, we stress that future research about which human or environmental factors interact to enable or to limit the persistence of large carnivores in human-dominated landscapes should try to integrate this human dimension.

On the other hand, some problems associated with differences in the spatial scale in which some variables were measured (particularly food availability) regarding the spatial scale we used to determine wolf occurrence could be also partly responsible for the large amount of unexplained variance. In fact, the influence of this factor is probably the rule in many studies about distribution or habitat modelling using large vertebrate species as study models. A possible solution to reduce this source of bias would be matching all the spatial scales in which the different factors are measured (for example counting the livestock within each grid-cell in the field); however, this procedure entails several logistic constraints given the spatial scale of these types of studies (around $30,000 \mathrm{~km}^{2}$ in this study or even at the scale of entire countries).

Wild boar and roe deer are the main wild prey of wolves in Galicia, although their role in the diet is only locally significant (Guitián et al., 1979; Sazatornil, 2008; Barja, 2009). Both 
species can adapt to remarkable levels of human activity living in agricultural landscapes (Sáez-Royuela \& Tellería, 1986; Andersen et al., 1998), particularly after the swift process of depopulation and land abandonment occurred during the last third of the 20th century. Thus, the adaptability of wild ungulates to human activity is facilitating the occurrence, persistence and recolonization of large predators in anthropogenic areas (e.g. Ensenrink \& Vogel, 2006; Basille et al., 2009; Mladenoff et al., 2009). Moreover, this fact may be buffering potential negative effects on wolf populations coexisting with humans related to changes in animal husbandry and livestock practices at short-medium term.

We found that horses living in semi-wild conditions in Galicia may be a key factor determining wolf occurrence in areas of low abundance of wild prey or other livestock species. Our results regarding the important contribution of the spatial correction term to the total variance explained in the food availability model suggest that the significant selected food types seemed to be rather aggregated than randomly distributed in Galicia. Moreover, the negative joint contribution of density of horses indicates that a proportion of the relationships between this factor and the other predictors are suppressive and not additive (Chevan \& Sutherland, 1991), particularly for those variables within the group of humans.

Regarding humans, two important differences appear in human-dominated landscapes when compared with other areas. First, human density was not selected as a determinant factor of wolf occurrence, contrary to the findings of other habitat suitability or predictive models (e.g. Mladenoff et al., 1995; Corsi et al., 1999; but see Theuerkauf, 2009 about the relationship between nocturnal activity of wolves and human density), with wolves occurring even in areas of high human density (247.6 inhabitants $\mathrm{km}^{-2}$ ). This fact shows the complex relationship between human density and the presence and persistence of large predators (e.g. Woodroffe, 2000; Linnell et al., 2001). Our results suggest that this factor itself is not decisive, but the spatial dispersion of human settlements, which could be a key factor determining the occurrence of large carnivores in human-dominated landscapes. In addition, the lack of relationship between human density and wolf presence could also be associated with the link between humans and the most important food sources for wolves (livestock and carrion) in the area. Second, threshold values for settlements and roads from which wolves are absent were remarkably higher than in other areas (e.g. Thiel, 1985; Mech, 1989; Mladenoff et al., 1995; Merrill, 2000; Theuerkauf, 2009). For example, the threshold value for paved road density is one of the highest values reported in the literature (Merrill, 2000; Blanco \& Cortés, 2007). Wolves in Galicia were present even in areas with remarkably high densities of paved roads $\left(3.7 \mathrm{~km} \mathrm{~km}^{-2}\right)$. Our results support the hypothesis that wolves show higher tolerance values for human factors in humandominated landscapes compared with non-human-dominated landscapes. On the other hand, the fact that wolves showed higher threshold values in human-dominated landscapes than in other areas alternatively suggest that wolves may have become more habituated to human presence over time in those areas of Europe where the species have persisted for long time (Nuñez-Quirós et al., 2007; see Thiel et al., 1998 for North America).

Wolves showed a strong positive selection towards elevated and hardly accessible sites as well as areas where vegetation structure provided refuge. The relatively new dense vegetation patches in much of the area (see for example Munilla-Rumbao et al., 2008) are favoring that wolves go unnoticed by humans. Overall, these variables indirectly reflect safe places from the human perspective (low human pressure) (Mladenoff et al., 1995; Jedrzejewski et al., 2008), although these places could also provide wild prey. The importance of landscape attributes may be exacerbated in human-dominated landscapes. Landscape attributes may facilitate wolf resting-refuge sites, movements, dispersal events and short-time colonization in areas where wolves were extinct (Gula et al., 2009).

Variation partitioning showed the importance of landscape attributes in determining the occurrence of wolves in humandominated landscapes. In fact, this block was involved in the three most important pure and joint effects determining the occurrence of this species. Likewise, hierarchical partitioning identified landscape attributes as the most important determinant of wolf occurrence. The large amount of joint effects and their importance across predictors of the three blocks provides evidence that in human-dominated landscapes the occurrence of wolves is the result of a complex interaction among several environmental and human factors, perhaps resulting in a regional variation in the species' sensitivity to humans.

Our results suggest that the strength of human pressure (indirectly estimated using landscape attributes) in determining wolf occurrence is more important than humans per se. Humans might not fully determine wolf occurrence except when additional factors facilitate wolf persecution. The occurrence of wolves in our study area seems to be highly influenced by landscape attributes and their interaction with humans, with food availability perhaps playing a secondary role reflecting the generalist trophic character of this species and a high availability of food resources for wolves in anthropogenic systems. Once food is available, wolves probably occur and persist in any place where human persecution is low (Boitani, 2000; Linnell et al., 2001; Musiani et al., 2010), even in human-dominated landscapes provided these areas fulfil this requirement (Blanco \& Cortés, 2007; Theuerkauf et al., 2007; Agarwala et al., 2010; this study). Landscape attributes may also facilitate spatio-temporal segregation of wolves from humans in anthropogenic landscapes (Theuerkauf et al., 2003).

Furthermore, the importance of landscape attributes along with their joint effects with humans in both variation partitioning and hierarchical partitioning suggests that the relationship between humans and wolf occurrence is modulated by the spatial context. In fact, the occupied grid-cells seemed aggregated rather than distributed (see Figure S1 in Supporting Information), making evident the importance of the landscape context in determining wolf occurrence. This is also borne out by the important contribution of the spatial 
correction term to the total variance explained $(38 \%$ in the general model).

In summary, in human-dominated landscapes, factors associated with the security of wolves (refuge) become more important. This fact may be particularly important in areas like Galicia where the human-wolf conflict is noticeable and where mortality seems to be mainly associated with humans. Thus, in our human-dominated landscape, the characteristics of the landscape - inaccessible sites with a remarkable amount of refuge - may have played a key role in the occurrence and persistence of this large predator throughout decades, even in those periods where human persecution was highest (e.g. around 1970s).

\section{ACKNOWLEDGEMENTS}

We are grateful to wolf biologists Pedro Alonso, Francisco Alvares, Emilio J. García, Jorge F. Layna, Andrés Ordiz, Vicente Palacios, Pablo Sierra and Antonio Uzal who have participated in the fieldwork. Wolf monitoring in Galicia was supported by Consellería de Medio Ambiente, Xunta de Galicia. We are very grateful to Belén Bris, Rogelio Fernández, Carmen Juliani, Mercedes Robles, Emilio Rosa, Jesús Santamarina and Javier Turrillo. We especially thank José Guitián, Thomas Meier, Javier Naves, Jonathan Jeschke, Marco Apollonio and two anonymous referees who critically reviewed an earlier version of this manuscript.

\section{REFERENCES}

Agarwala, M., Kumar, S., Treves, A. \& Naughton-Treves, L. (2010) Paying for wolves in Solapur, India and Wisconsin, USA: comparing compensation rules and practice to understand the goals and politics of wolf conservation. Biological Conservation, 143, 2945-2955.

Andersen, R., Duncan, P. \& Linnell, J.D.C. (1998) The European roe deer: the biology of success. Scandinavian University Press, Oslo.

Anderson, M.J. \& Gribble, N.A. (1998) Partitioning the variation among spatial, temporal and environmental components in a multivariate data set. Australian Journal of Ecology, 23, 158-167.

Barja, I. (2009) Prey and prey-age preference by the Iberian wolf Canis lupus signatus in a multiple-prey ecosystem. Wildlife Biology, $15,147-154$.

Barja, I., de Miguel, F.J. \& Bárcena, F. (2004) The importance of crossroads in faecal marking behaviour of the wolves. Naturwissenschaften, 91 , 489-492.

Basille, M., Herfindal, I., Santin-Janin, H., Linnell, J.D.C., Odden, J., Andersen, R., Arild Høgda, K. \& Gaillard, J. (2009) What shapes Eurasian lynx distribution in human dominated landscapes: selecting prey or avoiding people? Ecography, 32, 683-691.

Blanco, J.C. \& Cortés, Y. (2002) Ecología, censos, percepción y evolución del lobo en España: Análisis de un conflicto. SECEM, Málaga.
Blanco, J.C. \& Cortés, Y. (2007) Dispersal patterns, social structure and mortality of wolves living in agricultural habitats in Spain. Journal of Zoology, 273, 114-124.

Boitani, L. (1982) Wolf management in intensively used areas of Italy. Wolves of the world. Perspectives of behaviour, ecology, and conservation (ed. by F.H. Harrington and D.C. Paquet), pp. 158-172. Noyes Publications, Park Ridge.

Boitani, L. (2000) Action plan for the conservation of wolves (Canis lupus) in Europe. Council of Europe Publishing, Strasbourg, France.

Borcard, D., Legendre, P. \& Drapeau, P. (1992) Partialling out the spatial component of ecological variation. Ecology, 73, 1045-1055.

Burnham, K.P. \& Anderson, D.R. (2002) Model selection and multimodel inference. Springer-Verlag Inc., New York, NY.

Cardillo, M., Purvis, A., Sechrest, W., Gittleman, J.L., Bielby, J. \& Mace, G.M. (2004) Human population density and extinction risk in the world's carnivores. PLoS Biology, 2, 909-0914.

Chevan, A. \& Sutherland, M. (1991) Hierarchical partitioning. American Statistician, 45, 90-96.

Ciucci, P., Masi, M. \& Boitani, L. (2003) Winter habitat and travel route selection by wolves in the northern Apennines, Italy. Ecography, 26, 223-235.

Corsi, F., Dupre, F. \& Boitani, L. (1999) A large-scale model of wolf distribution in Italy for conservation planning. Conservation Biology, 13, 150-159.

Cuesta, L., Bárcena, F., Palacios, F. \& Reig, S. (1991) The trophic ecology of the Iberian wolf (Canis lupus signatus Cabrera, 1907). A new analysis of stomach's data. Mammalia, 55 , 239-254.

Ensenrink, M. \& Vogel, G. (2006) The carnivore comeback. Science, 314, 746-749.

Fritts, S.H., Stephenson, R.O., Hayes, R.D. \& Boitani, L. (2003) Wolves and humans. Wolves: behavior, ecology, and conservation (ed. by L.D. Mech and L. Boitani), pp. 289-316. The University of Chicago Press, Chicago, IL.

Fuller, T.K. (1989) Population dynamics of wolves in northcentral Minnesota. Wildlife Monographs, 105, 1-41.

Fuller, T.K. \& Sievert, P.R. (2001) Carnivore demography and the consequences of changes in prey availability. Carnivore conservation (ed. by J.L. Gittleman, S.M. Funk, D. Macdonald and R.K. Wayne), pp. 163-178. Cambridge University Press, Cambridge, UK.

Glenz, C., Massolo, D., Kuonen, D. \& Schlaepfer, R. (2001) A wolf habitat suitability prediction study in Valais (Switzerland). Landscape and Urban Planning, 55, 55-65.

Gómez-Sal, A., Álvarez, J., Muñoz-Yanguas, M.A. \& Rebollo, S. (1993) Patterns of change in the agrarian landscape in an area of the Cantabrian Mountains (Spain). Assessment by transition probabilities. Landscape ecology and agrosystems (ed. by R. Bunce, L. Ryzskowski and M. Paoletti), pp. 141152. Lewis Publishers, Boca Raton, FL.

Green, R.H. (1979). Sampling design and statistical methods for environmental biologists. John Wiley and Sons, New York, NY. 
Guitián, J., De Castro, A., Bas, S. \& Sánchez, J.L. (1979) Nota sobre la dieta del lobo (Canis lupus L.) en Galicia. Trabajos Compostelanos de Biología, 8, 95-104.

Gula, R., Hausknecht., R. \& Kuehn., R. (2009) Evidence of wolf dispersal in anthropogenic habitats of the Polish Carpathian Mountains. Biodiversity and Conservation, 18, 2173-2184.

Harris, R.B. \& Ream, R.R. (1983) A method to aid in discrimination of tracks from wolves and dogs. Wolves in Canada and Alaska (ed. by L.N. Carbyn). pp. 120-124. Canadian Wildlife Service. Report Series, 45.

Heikkinen, R.K., Luoto, M., Kuussaari, M. \& Pöyry, J. (2005) New insights into butterfly-environment relationships using partitioning methods. Proceedings of the Royal Society of London. Series B, 272, 2203-2210.

INE (2009) Censo de población y vivienda. Instituto Nacional de Estadística de España, Madrid, Spain.

Jedrzejewski, W., Jedrzejewska, B., Zawadzka, B., Borowik, T., Nowak, S. \& Mysajek, R.W. (2008) Habitat suitability model for Polish wolves based on long-term national census. Animal Conservation, $11,377-390$.

Jędrzejewski, W., Schmidt, K., Theuerkauf, J., Jędrzejewska, B. \& Kowalczyk, R. (2007) Territory size of wolves Canis lupus: linking local (Białowieża Primeval Forest, Poland) and Holarctic-scale patterns. Ecography, 30, 66-76.

Karlsson, J. \& Sjöström, M. (2011) Subsidized fencing of livestock as a means of increasing tolerance for wolves. Ecology and Society, 16, 16.

Legendre, P. \& Legendre, L. (1998) Numerical ecology, 2nd edn. Elsevier Science, Amsterdam.

Linnell, J.D.C., Swenson, J. \& Andersen, R. (2001) Predators and people: conservation of large carnivores is possible at high human densities if management policy is favourable. Animal Conservation, 4, 345-349.

Llaneza, L. \& Ordiz, A. (2003) Distribución y aspectos poblacionales del lobo ibérico en la provincia de Lugo. Galemys, 15, 55-66.

Llaneza, L., Álvares, F., Ordiz, A., Sierra, P. \& Uzal, A. (2004) Distribución y aspectos poblacionales del lobo ibérico en la provincia de Ourense. Ecología, 18, 227-238.

Llaneza, L., Palacios, V., Uzal, A., Ordiz, A., Sazatornil, V., Sierra, P. \& Álvares, F. (2005a) Distribución y aspectos poblacionales del lobo ibérico (Canis lupus signatus) en las provincias de Pontevedra y A Coruña. Galemys, 17, 61-80.

Llaneza, L., Ordiz, A., Palacios, V. \& Uzal, A. (2005b) Monitoring Wolf populations using points combined with sign surveys transects. Wildlife Biology in Practice, $1,108-117$.

Mac Nally, R. (2000) Regression and model building in conservation biology, biogeography and ecology: the distinction between - and reconciliation of - "predictive" and "explanatory" models. Biodiversity and Conservation,9, 655671.

Mac Nally, R. \& Horrocks, G. (2002) Relative influences of patch, landscape and historical factors on birds in an Australian fragmented landscape. Journal of Biogeography, 29, 395-410.
Massolo, A. \& Meriggi, A. (1998) Factors affecting habitat occupancy by wolves in northern Apennines (northern Italy): a model of habitat suitability. Ecography, 21, 97-107.

Mech, L.D. (1989) Wolf population survival in an area of high road density. American Midland Naturalist, 121, 387-389.

Mech, L.D. (1995) The challenge and opportunity of recovering wolf populations. Conservation Biology, 9, 270-278.

Mech, L.D. (2006) Prediction failure of a wolf landscape model. Wildife Society Bulletin, 34, 874-877.

Mech, L.D. \& Boitani, L. (2003) Wolves: behavior, ecology, conservation. University of Chicago Press, Chicago, IL.

Merrill, S.B. (2000) Road densities and Gray Wolf, Canis lupus, habitat suitability: an exception. Canadian Field Naturalist, 114, 312-313.

Mladenoff, D., Sickley, T.A., Haight, R.G. \& Wydeven, A.P. (1995) A regional landscape analysis and prediction of favourable gray wolf habitat in the northern great lakes region. Conservation Biology, 9, 279-294.

Mladenoff, D., Clayton, M.K., Pratt, S.P., Sickley, T.A. \& Wydeven, A.P. (2009) Change in occupied wolf habitat in the northern Great Lakes region. Recovery of Gray wolves in the Great Lakes region of the United States (ed. by A.P. Wydeven, T.R. van Deelen and A.J. Heske), pp. 119-138. Springer Science and Business Media, New York.

Munilla-Rumbao, I., López-Bao, J.V., González-Varo, J.P. \& Guitián, J. (2008) Long-term changes in the breeding bird assemblages of two woodland patches in northwest Spain. Ardeola, 55, 221-227.

Musiani, M., Boitani, L. \& Paquet, P. (2010) The world of wolves. New perspectives on ecology, behaviour and management. University of Calgary Press, Calgary, AB, Canada.

Naughton-Treves, L., Grossberg, R. \& Treves, A. (2003) Paying for tolerance: rural citizens' attitudes toward wolf depredation and compensation. Conservation Biology, 17, 1500-1511.

Nuñez-Quirós, P., García-Lavandera, R. \& Llaneza, L. (2007) Analysis of historical wolf (Canis lupus) distributions in Galicia: 1850, 1960 and 2003. Ecología, 21 , 195-205.

Palacios, V., García, E. \& Llaneza, L. (2009) Seguimiento del lobo en el norte de Lugo, 2008-2009. Technical report from the Consellería do Medio Rural. Xunta de Galicia.

Promberger, C. \& Schroder, W. (1993) Wolves in Europe: status and perspectives. Munich Wildlife Society, Ettal, Germany.

R Development Core Team. (2008) R: a language and environment for statistical computing. R Foundation for Statistical Computing, Vienna, Austria. ISBN 3-900051-07-0, Available at: http://www.R-project.org (accessed 11 January 2010).

Roura-Pascual, N., Pons, P., Etienne, M. \& Lambert, B. (2005) Transformation of a rural landscape in the Eastern Pyrenees between 1953 and 2000. Mountain Research and Development, $25,254-263$.

Ruíz de la Torre, J. (2001). Mapa Forestal de España. Escala 1:200.000. Ministerio de Agricultura. Pesca y Alimentación, Madrid.

Sáez-Royuela, C. \& Tellería, J.L. (1986) The increased population of wild boar (Sus scrofa L.) in Europe. Mammal Review, 16, 97-101. 
Sazatornil, V. (2008) Alimentación del lobo (Canis lupus) en zonas del Occidente de Galicia con presencia de ganado equino en régimen de semi-libertad. Msc Thesis, University of A Coruña, A Coruña, Spain.

Theuerkauf, J. (2009) What drives wolves: fear or hunger? humans, diet, climate and wolf activity patterns Ethology, 115, 649-657.

Theuerkauf, J., Jędrzejewski, W., Schmidt, K. \& Gula, R. (2003) Spatiotemporal segregation of wolves from humans in the Białowieża Forest (Poland). Journal of Wildlife Management, 67, 706-716.

Theuerkauf, J., Gula, R., Pirga, B., Tsunoda, H., Eggermann, J., Brzezowska, B., Rouys, S. \& Radler, S. (2007) Human impact on wolf activity in the Bieszczady mountains, SE Poland. Annales Zoologici Fennici, 44, 225-231.

Thiel, R.P. (1985) Relationship between road densities and wolf habitat suitability in Wisconsin. American Midland Naturalist, 113 , 404-407.

Thiel, R.P., Merrill, S. \& Mech, D. (1998) Tolerance by denning Wolves, Canis lupus, to human disturbance. Canadian Field Naturalist, 112, 340-342.

Valverde, J.A. (1971) El lobo español. Montes, 159, 229-241.

Walsh, C. \& Mac Nally, R. (2008) hier.part: hierarchical partitioning. $\mathrm{R}$ package version 1.0.3. R Foundation for Statistical Computing, Vienna, Austria.

Woodroffe, R. (2000) Predators and people: using human densities to interpret declines of large carnivores. Animal Conservation, 3 , 165-173.

Woodroffe, R. \& Ginsberg, J.R. (1998) Edge effects and the extinction of populations inside protected areas. Science, $\mathbf{2 8 0}$, 2126-2128.

Woodroffe, R., Thirgood, S. \& Rabinowitz, A. (2005) People and wildife: conflict or coexistence? Cambridge University Press, Cambridge, UK.

Xunta de Galicia (2005) Official Game Statistics, 2005. Environmental Council of Galicia, Santiago de Compostela, Spain.
Zub, K., Theuerkauf, J., Jedrzejewski, W., Jedrzejewska, B., Schmidt, K. \& Kowalczyk, R. (2003) Wolf pack territory marking in the Bialowieza primeval forest (Poland). Behaviour, 140, 635-648.

\section{SUPPORTING INFORMATION}

Additional Supporting Information may be found in the online version of this article:

Figure S1 Spatial distribution of the positive grid-cells for the presence of wolves (grey cells) in Galicia between 1999 and 2003.

As a service to our authors and readers, this journal provides supporting information supplied by the authors. Such materials are peer-reviewed and may be re-organized for online delivery, but are not copy-edited or typeset. Technical support issues arising from supporting information (other than missing files) should be addressed to the authors.

Luis Llaneza, José Vicente López-Bao and Víctor Sazatornil are wolf biologists interested in the ecology, management and conservation of large predators in humandominated landscapes.

Author contributions: J.V.L.B. and L.LL conceived the ideas; L.LL, J.V.L.B. and V.S. participated in the data collection; L.LL and J.V.L.B. analysed the data; L.LL, J.V.L.B. and V.S. led the writing. All authors commented on and revised earlier manuscript versions. 